\title{
Corporate Ethics, Personal Ethics: One and the Same? Identifying Ethical Captains of Industry
}

\author{
Helen Madden-Hallett \\ Victoria University, Australia
}

\begin{abstract}
This paper explores the relationship between the corporation and its ethical standing and that of its employees within a framework of eight dynamics. The 'highest' level of ethical behaviour possible for a corporation is only as 'high' as that of its personnel, especially those in positions of power. Companies that behave ethically are more profitable, while companies that behave unethically are stripping resources from society without fair exchange and leaving a legacy of anti-trust and non-cooperation between individuals and organisations as well as a dollar cost of approximately two and a half trillion dollars per year. In the long run they damage themselves and all dynamics in which they intersect. The problem then is how to find ethical personnel to staff organisations for the benefit of all related dynamics. This paper explores the idea of business as part of a greater whole and the scope of personal ethics especially in business. The paper then explores potential indicators of ethically minded individuals with a view to use this information when hiring new employees but particularly those who, when employed, will wield the greatest power: those at middle management and top management.
\end{abstract}

\section{Keywords}

Corporate ethics, religious affiliation, virtue ethics, business

\section{Dynamics of Existence}

As expressed so eloquently by Donne (1624) no person exists unto themselves but as a part of a family, a member in a group or several groups, a citizen in society and part of Mankind. Waddock (2005) suggests that a lack of connection between these various dynamics makes business people unaware of the repercussions of their poor business decisions and the financial cost which is estimated to be two and a half trillion dollars per year (Estes 1996). Waddock (2005) lists the dynamics as involving "stakeholders, societies, and the natural environment" and adds 'other people, organizations, communities' and further adds a still broader sweep by also including 'the world'. McMurtry (2002) also includes the world whilst adding 'life' in their discussion of the Free Trade Area of the Americas being 'life-blind' and not recognising the

Copyright (C) 2009 Victoria University. This document has been published as part of the Journal of Business Systems, Governance and Ethics in both online and print formats. Educational and non-profit institutions are granted a nonexclusive licence to utilise this document in whole or in part for personal or classroom use without fee, provided that correct attribution and citation are made and this copyright statement is reproduced. Any other usage is prohibited without the express permission of the publisher. rights of living entities. McMurtry's inclusion of 'the world' is taken to mean both the physical and social environment. Quinn (1997) suggests that environmental issues and impact on the physical environment are affected when business ethics are not practiced and they give examples of the Bhopal and Exxon Valdez incidents, amongst others.

1 From John Donne's Meditation XVII, “Devotions Upon Emergent Occasions” as contained in Alford (1839) 
A more orderly description of these various areas which may be impacted upon and resound back upon each other is provided by Hubbard (2007) as being eight dynamics in total: one's self, family, groups of individuals, Mankind, all living things, physical universe as made up of matter, energy, space and time, the spiritual realm and the Supreme Being. This model is hereafter used when referring to stakeholders as each to a greater or lesser degree is involved with each other, and although each holds a greater or lesser degree of importance for individuals they nevertheless influence each other. These dynamics are incorporated into a definition of ethics as behaviour which seeks the best level of survival, or 'the greatest benefits to the greatest number of dynamics' and conversely unethical behaviour is that which offers 'the poorest solution' and brings 'the greatest harm to the most number of dynamics' (Hubbard 2007). This is not to be taken as the $19^{\text {th }}$ century utilitarian view of the greatest good for the greatest number per se, but the greatest number of dynamics or divisions as set out previously.

Applying this model of dynamics to the business world shows the individual describing the first dynamic 'self', as being represented by an individual's personal interests such as career advancement, remuneration, bonuses and work conditions. This impinges upon and is impinged upon in turn by the next category, 'family'. Here corporations have sometimes, often through coercion from unions (Moody, 2007), introduced family friendly policies and conditions such as paid and unpaid parental leave, family leave and carer's leave as well as making provision for part-time work hours. On the less supportive side and edging toward unethical behaviour one has the manager who demands such high levels of productivity (with or without correct resource provision) that staff, wishing to remain employed, regularly work excessive hours. Long work hours can translate into neglect of one's family.

The third dynamic can be described as the corporation itself. Turner (2009) explains that the Corporations Act 2001 'recognises that every company has the legal capacity and powers of an individual, as well as a range of special corporate powers'. It operates essentially as a group of individuals which, as shown in the seminal case of Salomon v. Salomon and Co. Ltd., is deemed to have existence independently of those it comprises. This is perhaps the most commonly seen manifestation of an over emphasis on one dynamic. The corporation grown so large and powerful, especially in a nurturing environment of free capital markets, that there are no self-regulating mechanism and few external checks and measures to keep a balance with all other dynamics. This nurturing environment is exemplified in the Bush and Reagan administrations with the deregulation and lessening of control of the American banking system.

The expression of 'Mankind' as a dimension is typically represented in the corporate sector as the recipient of generous philanthropic acts. In the context of business corporations this often positively, takes the form of substantial donations to charities or the arts.

The next dynamic of all living things (including plants and animals), comes under scrutiny because Mankind's posture of 'conquer nature', at its peak in the Elizabethan age of exploration and trade, eventually evolved into economic rationalism whereby nature is seen as worthwhile preserving if there is financial gain. More recently sections of society are more attuned to a guardianship or stewardship role of preserving life for its own sake.

In the corporate sector an example of a positive application, is shown by companies taking a stand on environmentalism and conservations of resources, which, interestingly enough often coincides with economic benefits such as the reinvigoration of the Ford Rouge Centre, Dearborn Truck Plant, Michigan. The plant now boasts a living roof covering 10.4 acres which substantially reduces operational costs while simultaneously contributes to cleaner air, habitat for birds, small native rodents and insects, and reducing run off (Ford Motor Company 2009).

The converse is also apparent with corporations neglecting or actively participating in dubious enterprises which offer short term lucrative rewards at the expense of living things, including plants and animals.

The next dynamic is that of matter, energy, space and time which is manifested negatively in the corporate sector by their rapacious need for resources, such as primary materials for manufacturing and consumption and often their dependence upon non-renewable energy sources such as coal and oil. 
Here too progressive companies have adopted sustainable and renewable energy sources such as tidal, wind and solar power.

The final dynamic of the spiritual realm is perhaps not so obviously apparent in the corporate sector. On closer inspection though corporations rely on managers and employees exhibiting an alignment to the Protestant work ethic which is instrumental in driving modern capitalist systems. The belief that one can attain spiritual growth through the acquisition of wealth is consistent with many religious denominations including The Religious Society of Friends whose early parishioners were active in medicine and business. A notable example is their influence in developing thriving confectionary businesses founded by the families Cadbury, Fry and Rowntree (The Religious Society of Friends 2009). Their business acumen was motivated strongly by their religious views and was used in this instance to offer the public an alternative to alcoholic beverages in the form of drinking chocolate.

\section{The Ethical Dilemma}

Ethical dilemmas as those in which one dynamic is pitched against another without clear guidelines as to how to resolve the situation. It appears that those who operate more fully on the group (or work) dynamic are more likely to adhere to corporate rulings rather than their personal values (Arnold, Bernardi, Neidermeyer and Schmee 2005). This is in alignment with stewardship theory (Clarke 2007) in which employees act in the best interests of the corporations for whom they work, rather than looking more widely at the situation to reach the optimum number of positive outcomes across the majority of dynamics. The approach recommended here has leanings toward stakeholder theory (Donaldson and Preston 1995; Clarke 2007; Furneaux 2008) but includes wider dimensions than that proposed by stakeholder theory. Regardless of the model, the corporation can hold overwhelming influence over others and it in some instances it may only be an individual or small group that seeks to mitigate against that influence through a particular ethical stance not held by the corporation but desirable for society.

It is important to note that when individual behaviour is more closely aligned with Machiavellian principles, or in a way that significantly benefits the personal dynamic but is non-optimum across the majority of other dynamics, systems of monitoring and checking have to be developed to protect those same dynamics. This manner of opportunistic behaviour results in a lack of trust between individuals and organisations and substantial amounts of money are spent on 'checking and monitoring' (Noreen 1988).

\section{Hypocrisy at the Top}

Corporations exist as part of society. Their marketing decisions, product decisions, resource consumption, employment policies and all spheres of their endeavours have an immense impact upon society. The corporate boardrooms take the view that although it may be the case that the corporations they lead impact upon society, in some cases this appears to be of little concern. Their over-riding concern is in ensuring shareholders receive the highest possible return on their money whilst remaining inside the constraints of law, and by adherence to this view these same corporate leaders earn substantial salaries and substantial bonuses (Moody 2007). Some argue that this is all that is required of corporate leaders whilst others such as Child and Rodrigues (2003) express concern about the degree of power shown by corporations and the issues of honest disclosure practices. Brenner (1992) and Paine (1994) point out that some corporations actively seek ethical improvements through the creation of compliance or ethics programs because they understand the impact their organisations have on society.

While unethical behaviour creates significant costs, the reflection of this is also true with modern thinking corporate leaders realizing that their organisations are regulated by the power of society and that relates to their well being or indeed their continued existence. Kochan (2003) suggests that corporate leaders who have reflected on the current situation in the aftermath of numerous corporate scandals are endeavouring to reinvent the modern corporation so that it broadens its focus beyond financial targets and satisfactions of shareholders only. Kochan (2003) discusses the view that corporate leaders are seen as offering 'poor, greedy and/or unethical leadership' and that effort should 
be placed on transforming these individuals into decent people mainly through accurate disclosure (Braendle and Noll 2005), enforcement and criminal penalties.

It is important to note that managerial level staff have significant influence over those they supervise through their ethical philosophy and behaviour. Indeed, Stead et al. (1990) comment that ethical philosophies come to naught if managers do not exhibit ethical behaviour in the workplace. Waddock (2005) supports the importance of ethical behaviour by emphasising the significance of integrity when undertaking auditing procedures.

Rose (2007) argues that managers in business are reined in and are unable to make decisions by over viewing a situation with broad ethical considerations but are restricted to operating within the confines of legal compliance. To this end Rose (2007) goes on to state that captains of industry have a highly developed personal integrity. One could argue that being constrained by what is implied to be inadequate laws is a poor excuse for passivity. Passivity in the face of unethical thinking and behaviour is yet another form of an unacceptable lack of ethics. It is a harmful act by omission. In society and in business both the individual and the corporation are expected to act within their sphere of influence. For some individuals this sphere is narrow, for example, the ordinary man in the street who does not have easy access to politicians and the judiciary (for the purpose of creating and changing law). The common man, having recognised their limited reach joins a community group of like minded individuals which collectively advances their cause. Or they at least march in a rally (McMurtry 2002) or write their politician stating their concerns. The common man lobbies and transforms society but some corporate leaders do nothing all the while declaring that it is the law itself that restricts their powers to engender change for better outcomes.

It is speculated that corporate leaders have a wide sphere of influence within and without the boardroom and could behave pro-actively far more easily and more powerfully given their extensive 'reach', that is, by using their business contacts, corporate connections and family networks. Waddock (2005) suggests that top executives that act with integrity may also create mission statements that encourage and support 'accurate reporting' and Schwartz (2001) advances the idea that in some instances corporate codes could be considered "an important first step" in generating ethical corporate behaviour. Within the boardroom it is suggested that if the 'hard' questions were asked and answered with candour, many dubious circumstances would be curtailed early in the decision making process. Corporate leaders claim concern about the decline of ethical standards (Rose 2007) yet do nothing.

It is argued that there may be a conflict between personal values and those espoused by the corporation (Arnold, Bernardi et al. 2005) and this places employees in situations in which they are forced to choose between their professional duty and their personal mores. De George (2006) suggests that such codes do little to encourage employees to apply personal codes of ethics or be prepared to accept the consequences of their actions. "Rarely, if ever, does the code suggest employees use their moral reasoning skills or moral imagination and take moral responsibility for their actions" (De George 2006) If one were to look at ethics as an active process and not just an outcome, such apparent conflicts could be more readily resolved. Employees would not only look for 'the answer' but could be part of the process by proactively participating in the evolution of optimum solutions which feed back into the body of corporate guidelines.

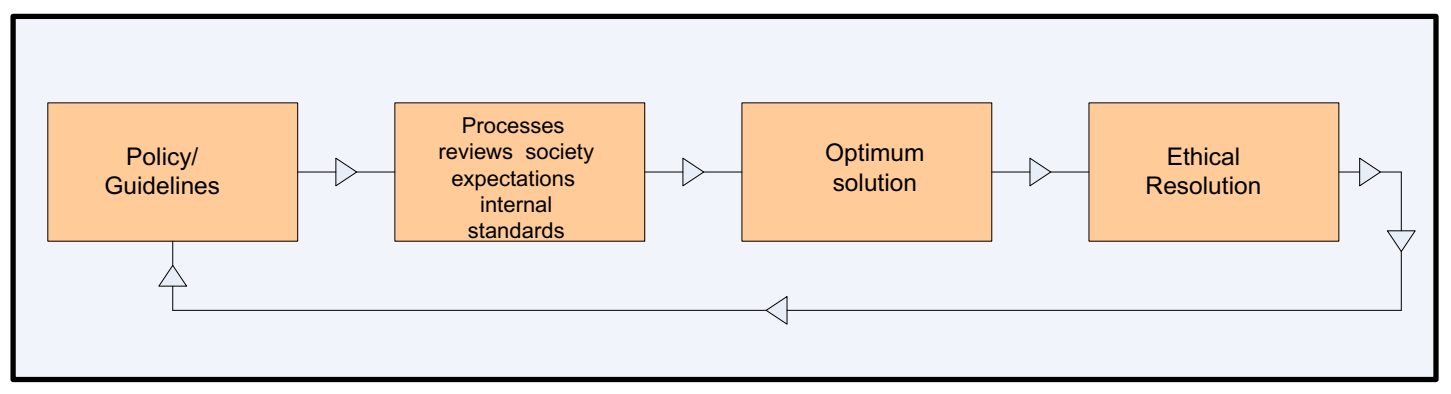

Figure 1. Ethical Feedback Loop

It is the radical thinkers and doers that proactively take responsibility, sometimes by lobbying public and private entities, governments and changing the law itself. One such example is the 'Garbage 
Warrior', Mr. Michael Reynolds, an architect, who coined the term 'biotecture'. His philosophy clearly shows his pro-active approach: "I can't change the world, but I can make change anywhere that I am."(Reynolds 2009). From a limited power base he is seeking to change existing legislation so that environmentally friendly housing (in the fullest sense) known as 'Earth Ships' can legally be built in New Mexico, U.S.A. As the 21st Century quickens its pace and new holistic paradigms are becoming reality, consumers are no longer satisfied or pacified, as suggested by McMurtry, (2002) with corporations believing they have fulfilled their fiduciary duty by doing no harm. Consumers' expectations are that corporations should pro-actively seek to do good and contribute to society (Svensson and Wood 2007). This attitude is also apparent in the rise in popularity of socially responsible investment whereby investors show concern about the natural environment and society (Waring and Edwards 2008).

\section{Virtue Ethics}

The field of business ethics predominately focuses on the negative: corporate collapse, corruption and fraudulent practice but by doing so one can overlook the very real benefits which can accrue from adherence to ethical business practices. The positive side to business ethics (De George 1987) includes such areas as the correlation between adherence to ethical principals and increased profits, the enhancement of long range thinking and the benefits of trust between dynamics.

The growth in popularity of socially responsible investment indicates that investors themselves are expressing interest and support for an ethically positive approach to business (Waring and Edwards 2008). Another aspect to a positive application of ethics is expressed by Badaracco (2003) in their discussion of corporate leaders who seek to operate positively on all dynamics by recognising that rules are important but so too are the greater moral guidelines behind those rules. It is adherence to the spirit of the agreed upon rules that develops trust (Ritchie 1996), which in turn brings customers and job seekers wanting to be associated with the ideals as expressed and practiced by the ethical organisation. To create this atmosphere the corporations themselves must establish appropriate incentives.

\section{Corporations Reinventing Themselves}

What is needed is to reward ethical behaviour so that ethical individuals are encouraged to continue behaving well, acting as role models and remaining with their organisations. In this way the organisation can benefit because higher profits are to be had if the organisation operates as a good corporate citizen (Rogers and Gago 2004). To achieve this, the organisation needs ethical staff operating in a supportive environment. Ethical staff also need to be retained so the organisation will continue to helix upward becoming more ethical with each turn. The corporation is influenced by the individual, and conversely the individual is influenced by the corporation. The problem then is to create a critical mass of ethical people who will self-generate ethical colleagues by their modelling of behaviour, guidance through ethics policies (mission statements, compliance programs, codes of ethics and corporate credos, etc.), (Schwartz 2001) and understanding of the corporation's place as one dynamic among many.

To generate an influx of ethically minded and ethically acting people recruitment processes must review the criteria of characteristics and qualities they seek and the degree of importance placed on each attribute. In particular recruitment staff are advised to select those who have sufficient appropriate exposure to key characteristics as identified in the academic literature: a high level of education, a participant in a religious order, personal behaviour that conforms to or exceeds society's mores of right conduct and previous membership in corporations that exhibited good corporate citizenship, that is, people who rate highly on identified ethical indicators.

\section{Ethical Indicators}

The purpose of creating ethical indicators is so they may be tentatively used as a predictive tool allowing potential employers to hire staff who are more likely to exhibit behaviour consistent with the positive and ethical end of the spectrum. Concern that there is a lack of predictive tools is also 
expressed by Jennings (2006) when formulating corporate indicators of ethical collapse. Individual and situational factors come into play such as a person's personality and the organisation's systems of enforcement (Stead, Worrell et al. 1990). It is posited that the following factors would serve well: education, religious affiliation, personal ideologies, reputation and behaviour and corporate citizenship. A detailed questionnaire that pits one dynamic against another would provide an insight to potential employees' ability to juggle the eight dynamics successfully. This is especially important when there are limited guidelines for employees to follow.

\section{Education}

The better educated a society the more able is that society to observe, comment upon and take action against questionable conduct (Svensson and Wood 2007). The level of education in the corporate boardrooms and corporate middle management may be one indicator of the likelihood of accurate observation and critical debate. This does not pre-suppose that education alone generates ethical behaviour; rather it provides the requisite skills for analysis. Although not a guarantee of survival, choices across a majority of dynamics (in business parlance: optimum outcomes for the majority of stakeholder groups) it is more likely that educated staff would have skills necessary for critical review and communication.

\section{Religious Affiliation}

Religious affiliation it is argued influences one's proclivity toward ethical behaviour (Hunt and Vitell 1993; Quinn 1997; Longenecker, McKinney and Moore 2004). There is some debate however, as to whether one is a religious participant because one already exhibits and professes spiritual beliefs and deontological concerns or whether participation in established religion leads to such beliefs. Regardless of its genesis religious people are more likely to have 'more clearly defined'(Hunt and Vitell 1993) moral aspirations and this would strongly influence 'ethical judgments' (Hunt and Vitell, 1993). Religious participation may then be considered as a contributing component in judging the degree of importance placed on ethics by an individual and Brammer, Williams and Zinkin (2007) stipulate that the majority of religious groups do exhibit a higher level of expectation about companies' commitment to a variety of social issues. This is supported by Fernando et al. (2007) in their study of 80 Australian managers in which the question of recruitment is raised. The authors do not make recommendations about possible adjustments to recruitment processes so that religious affiliation could be revealed and it is suggested that this issue in itself is contentious.

Support is found for the inclusion of religion in the debate about business ethics from Fort (1997) who holds that an exclusionist approach, that is, excluding religious affiliation, is unnecessarily limiting. Nevertheless it is of importance to further investigate the relationship between religious affiliation and ethical behaviour especially if one adheres to Schwartz's (2006) view that there is a marked rise of spirituality in the workplace. A further argument for additional investigation into the relationship (or not) between religious affiliation and business ethics is that to date there are mixed results across various studies (Singhapakdi, Marta, Rallapalli and Rao 2000; Parboteeah, Hoegl and Cullen 2008). Nevertheless it is of importance to further investigate the relationship between religious affiliation and ethical behaviour because people who have formal adherence to religion may still behave badly.

\section{Personal ideologies, reputation and behaviour}

Employees often see themselves as able to act only as ethically as the organisation permits. The organisation has been shaped by past employees and is continually reshaped by current employees to reach its current ethical form. This is supported by Illes (2007) in their study on leadership in which it was revealed that ethical problems are solved in a way that is consistent with a person's personal values. An earlier study by Paine (1994) revealed the converse relationship which showed that one's personal values become aligned with that of the organisation and 'ethics has everything to do with management' such that the ethical tone is set by management. This reveals the value of ethical leaders, that is, those that model the personalism theme of desiring to create value for the group and not for themselves first (Whetstone 2002). Nevertheless creating value for the group is a sub-optimum solution if the leader is not also able to create value for themselves. 
Applying the theory of personalism and specifically the servant leadership model as used by Whetstone (2002) is problematic only if one takes this paradigm to its fullest extent. However it can be applied well in conjunction with the 'dynamics' model proposed earlier. Against this backdrop with creative insight, a corporate leader faced with an ethical dilemma may be able to resolve problems with outcomes that adhere to ethical standards, benefit the group, and benefit the decision maker. This is possible by understanding that the decision maker is a functioning part of their dynamics so that even at a secondary level the decision maker is benefited. For example, a decision made to increase foreman's pay but not manager's pay still benefits the manager if not in the most immediate sense but at least in the future by securing higher productivity and therefore greater security in the continuance of the firm.

This lends itself in part to Forsyth's (1980) discussion of relativism, in which 'the individual rejects universal moral rules' and idealism, in which it is believed that 'desirable' outcomes can 'always be obtained' by following right action. Forsyth established a taxonomy describing four types of ethical ideologies which, while offering valid insight, cannot be used as a predictive tool to gauge the degree of ethical behaviour. In the corporate environment one may use the taxonomy retrospectively by establishing the number of employees in each ideology and then developing relevant deterrents and incentives in the form of procedures, leadership models, rules, codes of ethics and corporate ideologies to which employees may adhere and be moderated appropriately by their self-selected classification.

Although this may provide as close to an ideal setting as could be developed, nevertheless it does not measure employees' application of their espoused ethical standards. The saying is not the doing and until the deed is done it is more a matter of conscience than ethics. A judgement of ethical standards can be made more accurately by inspecting actual past behaviour. As in business forecasting one may partly rely on historical behaviour to predict future behaviour under similar circumstances. So it is proposed that a predictive model be investigated by researching the relationship (or not) between a business person's education, religious affiliation, personal ideologies, reputation and behaviour, and finally corporate citizenship.

\section{Good Corporate Citizenship}

Affiliation with corporations that have achieved the reputation of good corporate citizenship may also be an indicator or a person's ethical leanings. Such a corporation earns its reputation by having known and used codes of conduct and an understanding and appreciation of its place in society.

It may be difficult to discern whether the codes are mere tokenism or an intended and genuine application of ethical standards to business (Weaver, Trevino and Cochran 1999). Although it is recognised that a corporate ethics program does not ensure good corporate behaviour it is at the very least the genesis of change. An individual employed in an atmosphere of good conduct is inevitably influenced by the 'explicit and implicit components' (Brenner 1992). As such it may also be used as one indicator of a person's likely behaviour with those having many years exposure in such an environment, rated more highly than those with fewer years employed in such an environment.

\section{Conclusion}

The challenge in the corporate sector is to proactively rethink the old paradigm of profits above all else and envisage an environment whereby the eight dynamics of existence can operate symbiotically. The corporate sector would benefit through encouraging ethical behaviour and thereby increased profits, a more visionary approach and greater trust and co-operation between dynamics. A predictive model to detect ethical behaviour has been tentatively suggested in this paper which if applied could greatly enhance a corporation's prospects of attracting and retaining ethical staff. The predictive model of personal and corporate ethical behaviour is based on level of education, religious affiliation (if any), personal ideologies, reputation and behaviour and lastly affiliation with corporations that are seen to have achieved good corporate citizenship.

The development of such a predictive tool would greatly enhance the operating environment of the corporate sector and all areas of society in which the corporate sector extends its reach. Suggested areas of further investigation may involve exploratory research drawing upon secondary data, taking 
the form of an information review from public sources identifying a limited number of corporate leaders whose organisations have not been involved in scandals and whose organisations have a high Corporate Ethical Values score could be undertaken. Personal interviews could be conducted with the identified corporate leaders to establish their degree of adherence or disengagement with the items in the proposed predictive model as suggested earlier.

The outcome of such a study could provide a valuable insight to the range of ethical considerations faced by corporate leaders and establish the framework for a practical predictive ethical testing agent.

\section{Reference List}

Arnold, F. D., Bernardi, R. A., Neidermeyer, P. E. and Schmee, J. (2005). "Personal versus professional ethics in confidentiality decisions: an exploratory study in Western Europe." Business Ethics: A European Review 14(3).

Badaracco, J. L. (2003). We Don't Need Another Hero. Harvard Business Review on Corporate Ethics. Boston, Harvard Business School Press: 1-17.

Braendle, U. C. and Noll, J. (2005). "A Fig Leaf for the Naked Corporation." Journal of Management and Governance(9): 79 - 99.

Brammer, S., Williams, G. and Zinkin, J. (2007). "Religion and Attitudes to Corporate Social Responsibility in a Large Cross-Country Sample “ Journal of Business Ethics 71(3): 229-243.

Brenner, S. N. (1992). "Ethics Programs and Their Dimensions." Journal of Business Ethics 11: 391399

Child, J. and Rodrigues, S. (2003). "The International Crisis of Confidence in Corporations." Journal of Management and Governance 7: 233-240.

Clarke, T. (2007). International Corporate Governance: A Comparative Approach, Routledge.

De George, R. T. (1987). "The Status of Business Ethics Past and Future.” Journal of Business Ethics 6: $201-211$.

De George, R. T. (2006). "An American perspective on corporate social responsibility and the tenuous relevance of Jacques Derrida." Business Ethics: A European Review 17(1): 74-86.

Donaldson, T. and Preston, L. (1995). "The stakeholder theory of the modern corporation: Concepts, evidence and implications." Academy of Management Review 20: 65-91.

Estes, R. (1996). Tyranny of the Bottom Line. San Francisco, CA, Berrett-Koehler Publishers.

Fernando, M., Dharmage, S. and Almeida, S. (2007). "Ethical Ideologies of Senior Australian Managers: An Empirical Study.” Journal of Business Ethics 82: 145-155.

Ford Motor Company. (2009). "Dearborn Truck Plant is a Model of Flexible and Sustainable Manufacturing." Retrieved 26 June, 2009, from www.ford.com.

Forsyth, D. R. (1980). "A Taxonomy of Ethical Ideologies.” Journal of Personality and Social Psychology 39(1): 175-184.

Fort, T. L. (1997). "Religion and Business Ethics: The Lessons from Political Morality " Journal of Business Ethics 16(3): 263-273.

Furneaux, B. (2008, This page was last modified 16:02, 28 January 2008). "Stakeholder Theory." Retrieved 14 September, 2008.

Hubbard, R. L. (2007). Introduction to Scientology Ethics. Copenhagen, Denmark, New Era Publications.

Hunt, S. D. and Vitell, S. (1993). The General Theory of Marketing Ethics: A Retrospective and Revision. Ethics in Marketing. Smith, N. C. and Quelch, J. A. Illinois, Irwin, Homewood.

Illes, J. J. (2007). "Responding Destructively in Leadership Situations: The Role of Personal Values and Problem Construction." Journal of Business Ethics 82: 251-272.

Jennings, M. M. (2006). The Seven Signs of Ethical Collapse. New York, St. Martin's Press.

Kochan, T. A. (2003). "Restoring Trust in American Corporations: Addressing the Root Cause." Journal of Management and Governance(7): 223-231.

Longenecker, J. G., McKinney, J. A. and Moore, C. W. (2004). "Religious Intensity, Evangelical Christianity, and Business Ethics: An Empirical Study." Journal of Business Ethics 55: 373-386.

McMurtry, J. (2002). "Why the Protestors Are Against Corporate Globalization." Journal of Business Ethics 40: 201-205. 
Moody, K. (2007). US Labor in Trouble and Transition. The Failure of Reform From Above, the Promise of Revival From Below. London, Verso.

Noreen, E. (1988). "The economics of ethics: A new perspective on agency theory." Accounting, Organizations and Society 13(4): 359-370.

Paine, L. S. (1994). "Managing for Organizational Integrity." Harvard Business Review(Mar - Apr): $106-117$.

Parboteeah, K. P., Hoegl, M. and Cullen, J. B. (2008). "Ethics and Religion: An Empirical Test of a Multidimensional Model “ Journal of Business Ethics 80(2): 387-398.

Quinn, J. J. (1997). "Personal Ethics and Business Ethics: The Ethical Attitudes of Owner/Managers of Small Business." Journal of Business Ethics(16): 119 - 127.

Reynolds, M. (2009). "Garbage Warrior." Retrieved May, 2009, from http://www.garbagewarrior.com/index.php.

Ritchie, F. (1996). Finishing First With Ethics: Bringing good business principles and sound ethics together for greater profits and a better future. Sydney, Business \& Professional Publishing.

Rogers, W. and Gago, S. (2004). "Stakeholder Influence on Corporate Strategies Over Time." Journal of Business Ethics 52: 349-363.

Rose, J. M. (2007). "Corporate Directors and Social Responsibility: Ethics versus Shareholder Value." Journal of Business Ethics 73: 319-331.

Schwartz, M. (2001). "The Nature of the Relationship between Corporate Codes of Ethics and Behaviour." Journal of Business Ethics 32: 247-262.

Schwartz, M. S. (2006). "God as a Managerial Stakeholder?” Journal of Business Ethics 66(2-3).

Singhapakdi, A., Marta, J. K., Rallapalli, K. C. and Rao, C. P. (2000). "Toward an Understanding of Religiousness and Marketing Ethics: An Empirical Study “ Journal of Business Ethics 27(4): 305319

Stead, E. W., Worrell, D. L. and Stead, G. J. (1990). "An Integrative Model for Understanding and Managing Ethical Behavior in Business Organizations." Journal of Business Ethics 9: 233-242.

Svensson, G. and Wood, G. (2007). "A Model of Business Ethics." Journal of Business Ethics 77: 303-322.

The Religious Society of Friends. (2009). "English Quakers Establish Chocolate Businesses." Retrieved 24 June, 2009, from www.quakerinfo.com.

Turner, C. (2009). Australian Commercial Law. Sydney, Thomson Reuters.

Waddock, S. (2005). "Hollow Men and Women at the Helm... Hollow Accounting Ethics?" Issues in Accounting Education 20: 145 -150.

Waring, P. and Edwards, T. (2008). "Socially Responsible Investment: Explaining its Uneven Development and Human Resource Management Consequences." Socially Responsible Investment 16(3): 135-145.

Weaver, G. R., Trevino, L. K. and Cochran, P. L. (1999). "Corporate Ethics Practices in the Mid 1990's: An Empirical Study of the Fortune 1000 “ Journal of Business Ethics 18: 283-294.

Whetstone, J. T. (2002). "Personalism and moral leadership: the servant leader with a transforming vision." Business Ethics: A European Review 11(4). 
